\title{
Expression of the Chimeric Pea PSPAL2 Promoter in Transgenic Tobacco in Response to Fungal Ingress and Injury
}

\author{
Permpong SRIPRASERTSAK ${ }^{* * *}$, Andi SAlamaH*, Yoshiyuki IMURA*, \\ Yuki ICHINOSE*, Tomonori SHIRAISHI* and Tetsuji YAMADA*
}

\begin{abstract}
The $5^{\prime}$-upstream region of the pea phenylalanine ammonia-lyase gene2 (PSPAL2-FL, -2196 to +110$)$ promoter was dissected by deleting in a series and fused to the coding region of the reporter gene encoding $\beta$-glucuronidase (GUS). The constructed chimeric promoters designated as PSPAL2-FLd1 $(-1486$ to +110$)$, PSPAL2-FLd2 (-966 to +110), PSPAL2-FLd3 $(-594$ to +110$)$ and the full-length promoter PSPAL2-FL $(-2196$ to +110$)$ were used to transform tobacco plants by the Agrobacteriummediated leaf disk method. Histochemically, GUS expression of the PSPAL2 promoter was examined in mature leaves of these transgenic tobacco leaves inoculated with pathogenic and non pathogenic fungi. GUS expression was induced by inoculation with a non pathogen, Phytophthora capsici, as detected by a very clear expression zone around the hypersensitive response (HR) area, especially in the transformants of PSPAL2-FL and PSPAL2-FLd1. However, on leaves inoculated with a pathogen, $P$. nicotianae, only weak and hazy colorations were detected around the inoculation site even in the transformant of PSPAL2-FL. Moreover, wounding mature leaves with a sterile razor blade also triggered remarkable expression around the wounded sites, especially in the transformant of PSPAL2-FL. We suggest that $P S P A L 2$ promoter expression in transgenic tobacco is induced not only by fungal ingression but also by wounding.
\end{abstract}

(Received September 10, 1998 ; Accepted December 7, 1998)

Key words: Pisum sativum, phenylalanine ammonia-lyase gene2 (PSPAL2), promoter activity, Phytophthora nicotianae, Agrobacterium-mediated transformation, transgenic tobacco.

\section{INTRODUCTION}

Higher plants acquired defensive systems for survival under versatile environmental stresses. The phenylpropanoid biosynthetic pathway provides precursors for the elaboration of a variety of compounds with different functions. These include structural components of cell walls, such as lignins which impregnate xylem cell walls during differentiation, and suberin which is an integral constituent of the cell wall matrix in endodermal and phellogen tissues, and a wide variety of natural products such as anthocyanins, phytoalexins, absorbent of ultraviolet (UV), and cytokinin-like substances ${ }^{9}$. A great number of genes encoding enzymes involved in the biosynthesis of phytoalexins, genes encoding other enzymes such as glucanase and chitinase that are antagonistic to pathogens, and genes associated with the deposition of structural polymers such as lignin and cell wall hydroxyproline-rich glycoproteins, have been investigated in relation to resistant responses induced by biotic or abiotic elicitors ${ }^{1,4,6,7,25)}$. The activation of these defense-related genes after inoculation with fungal or bacterial pathogens has also been shown in a number of plant-pathogen interactions ${ }^{12,21,26)}$.

Phenylalanine ammonia-lyase (PAL, EC 4.3.1.5) is one of the key enzymes that are essential for defense reactions in plants. PAL catalyzes the first step of the general phenylpropanoid metabolism, the deamination of L-phenylalanine to produce cinnamic acid, and regulates subsequent reactions leading to the production of a wide variety of natural products. These essential roles of isoflavonoids in plant development and defense responses against various environmental stresses, including pathogen ingression, and the structural and regulatory function of phenylalanine ammonia-lyase $(P A L)$ genes, have been extensively studied in various higher plants such as alfalfa ${ }^{13)}$, Arabidopsis ${ }^{30,36,46)}$, carrot $^{43)}$, French bean ${ }^{37,39)}$, Lithospermum erythrorhizon ${ }^{50)}$, parsley $^{29)}$, pea ${ }^{49)}$, pine ${ }^{47)}$, poplar ${ }^{42)}$, rice ${ }^{34,51)}$, sweet potato $^{44)}$, tobacco $^{10)}$ and tomato ${ }^{27)}$.

In pea, genes encoding phenylalanine ammonia-lyase

* Laboratory of Plant Pathology and Genetic Engineering, College of Agriculture, Okayama University, Tsushima Okayama 700-8530, Japan 岡山大学農学部

** Present address : Central Laboratory and Greenhouse Complex, Kasetsart University Research and Development Institute, Kasetsart University, Kamphaengsaen, Nakhon Pathom 73140, Thailand 
(PSPAL) form a small multigene family comprised of at least three members ${ }^{23}$. Two members of a PSPAL family, designated as PSPAL1 and PSPAL2, were cloned and characterized $^{48)}$. Both PSPAL1 and PSPAL2 were induced by fungal elicitors but suppressed by fungal suppressors produced by a pea pathogen, Mycosphaerella pinodes (Berk. et Blox.) Stone, a fungus pathogenic on pea $^{49)}$. The structures of two suppressors from $M$. pinodes were determined and named as Supprescin A and Supprescin $\mathrm{B}^{40)}$. Moreover, it was shown that the putative receptor for these suppressors might be a protein that tightly binds to cell wall-bound ATPase or the ATPase itself ${ }^{24)}$.

Current molecular study of plant defense genes has been focused on the expression and regulation of promoters that are associated with the specific induction of certain enzymes and proteins. In most cases, the mechanisms have been analyzed by monitoring transient expression of a reporter gene of chloramphenicol acetyltransferase (CAT) in electroporated protoplasts and/or the expression of $\beta$-glucuronidase (GUS) in tissues of transgenic plants ${ }^{2,5,6,8,17,28,32,41)}$. Recently, the temporal and spatial expression pattern of the PSPAL1 promoter was characterized in response to pathogen ingress and wounding in transgenic tobacco plants ${ }^{23)}$. The promoter dissection of PSPAL2 has been performed in a transient transforming assay by electroporation of pea protoplasts, then determining their responses to environmental stimuli such as fungal elicitors, Supprescin or UV light irradiation ${ }^{49)}$. Functional analysis of $5^{\prime}$-nested deletions showed that an enhancer-like element is located in the TATA-distal region from -2196 to -406 , in which the consensus sequence motifs known as box I, box II and box $\mathrm{IV}^{29,48)}$ were present in close proximity.

The objective of the present study is to elucidate the role of the $5^{\prime}$-upstream region of pea PSPAL2 promoter in responses of transgenic tobacco plant tissues to microbial invasion.

\section{MATERIALS AND METHODS}

Plant material and transformation Nicotiana tabacum cv. Xanthi NC (kindly provided by Japan Tobacco, Inc.) was used in the transformation experiments. Seeds were surface-sterilized in 5\% hypochlorite for $10 \mathrm{~min}$, followed by soaking in $70 \%$ ethanol for 10 min, and rinsing in sterilized water. Sterilized seeds were germinated in a sterile petri dish containing MS medium as described by Murashige and Skoog ${ }^{35)}$. A leaf disk of the sterilized tobacco was co-cultured in MS medium for $15-30 \mathrm{~min}$ with $1-5 \times 10^{8} \mathrm{cell} / \mathrm{ml}$ of Agrobacterium tumefaciens LBA4404 ${ }^{31)}$ carrying the specified chimeric genes as will be described. After drying on a sterilized Whatman 3MM filter paper to remove excess bacteria, inoculated leaf disks were placed abaxial surface down on MS medium containing NAA $0.1 \mathrm{mg} / 1$, $\mathrm{BA} 1.0 \mathrm{mg} / \mathrm{l}$. The inoculated leaves were incubated at $22-24^{\circ} \mathrm{C}$ for 2 days, then transferred onto MS-selective medium containing the same concentration of NAA, BA and supplemented with kanamycin $(100 \mathrm{mg} / \mathrm{l})$ and craforan $(500 \mathrm{mg} / \mathrm{l})$ until shoots formed. After 2-3 weeks of incubation, adventitious shoots were transferred to new MS medium and incubated until roots formed ${ }^{11)}$. All plant materials were incubated at $22-24^{\circ} \mathrm{C}$ under 16-hr light $\left(150 \mu \mathrm{E} / \mathrm{m}^{2} / \mathrm{s}\right)$, 8-hr dark conditions. Young seedlings were transplanted into soil and incubated in a greenhouse.

PAL-GUS chimeric gene fusions The pea PSPAL2 full-length promoter (PSPAL2-FL) and the deleted chimeric promoters had been constructed into CAT reporter gene for analyzing the transient expression in electroporated protoplasts ${ }^{48}$. To investigate the expression of PSPAL2 promoter in transgenic tobacco plants, the PSPAL2-FL promoter and the three selected deletion construct promoters in the CAT reporter gene were amplified by PCR using specific primers and subcloned into pBluescriptII $\mathrm{KS}(+)$ at HindIII and Bam HI sites, then ligated to pBI101.2 in frame of GUS reporter gene. The PSPAL2-GUS chimeric promoter constructs were purified and transformed into-A. tumefaciens LBA4404 by the freeze-thaw method ${ }^{18)}$.

GUS-PCR and DNA manipulation Genomic DNA extraction for GUS-PCR was performed as described by Hosaka ${ }^{19)}$. GUS-PCR was amplified using GUS-specific primers. DNA manipulation was performed according to the standard methods described by Sambrook et al. ${ }^{38)}$ or as specified by the manufacturer's protocols.

Histochemical GUS Assay Mature leaves were fixed by soaking in $1 \%$ formaldehyde in $50 \mathrm{mM}$ sodium phosphate buffer (pH 7.0) for $10 \mathrm{~min}$ and rinsed three times with $50 \mathrm{mM}$ sodium phosphate buffer ( $\mathrm{pH} 7.0$ ). Then, they were incubated in X-Gluc solution $(1.0 \mathrm{mM}$ 5 -bromo-4-chloro-3-indolyl $\beta$-D-glucuronide) in $50 \mathrm{mM}$ sodium phosphate buffer $(\mathrm{pH} 7.0), 0.5 \mathrm{mM}$ potassium ferricyanide, $0.5 \mathrm{mM}$ potassium ferrocyanide, $10 \mathrm{mM}$ EDTA at $37^{\circ} \mathrm{C}$ overnight as described by Jefferson et $a l{ }^{22)}$. Penetration and fixation of X-Gluc solution into tissues was facilitated by vacuum infiltration. Staining reactions were stopped by transferring the tissues into $70 \%$ ethanol.

Wounding and Inoculation Fungi used in this study were Phytophthora nicotianae van Breda de Haan var nicotianae Waterhouse, Po5 ( $P$. nicotianae), a tobacco pathogen, and $P$. capsici Leonian IKEDA-1, a nonpathogen of tobacco. Fungal mycelia were scraped off PDA media and used to inoculate tobacco leaves which had been sterilized with $70 \%$ ethanol, at the site where a cross-cut was made with a sterile razor blade for aiding fungal invasion. The GUS expression of the transformants was histochemically detected as previously described. 


\section{RESULTS}

\section{Histochemical GUS expression}

The translational PSPAL2-GUS fusion, PSPAL2-FL $(-2196$ to +110$)$ and three deleted chimeric promoters designated as PSPAL2-FLd1 (-1486 to +110), PSPAL2FLd2 (-966 to +110) and PSPAL2-FLd3 (-594 to +110 ) were used to transform tobacco plants (Fig. 1). The integration of PSPAL2-GUS fusions in the genome of transgenic tobacco plants was confirmed by PCR analysis using GUS-specific primers. Representative observations with at least three independent tobaccotransformant lines are shown in Plate I. The leaves of transgenic tobacco plants carrying PSPAL2-FL or chimeric promoter constructs were inoculated with $P$. nicotianae, a tobacco pathogenic fungi $(\mathrm{P})$ or with $P$. capsici, a nonpathogen (NP). The results showed that histochemically detected GUS expression in transgenic tobacco plants was highest at $48 \mathrm{hr}$ when incubated at $22-24^{\circ} \mathrm{C}$ and gradually faded at the hypersensitive response (HR) area around the inoculation site after 72
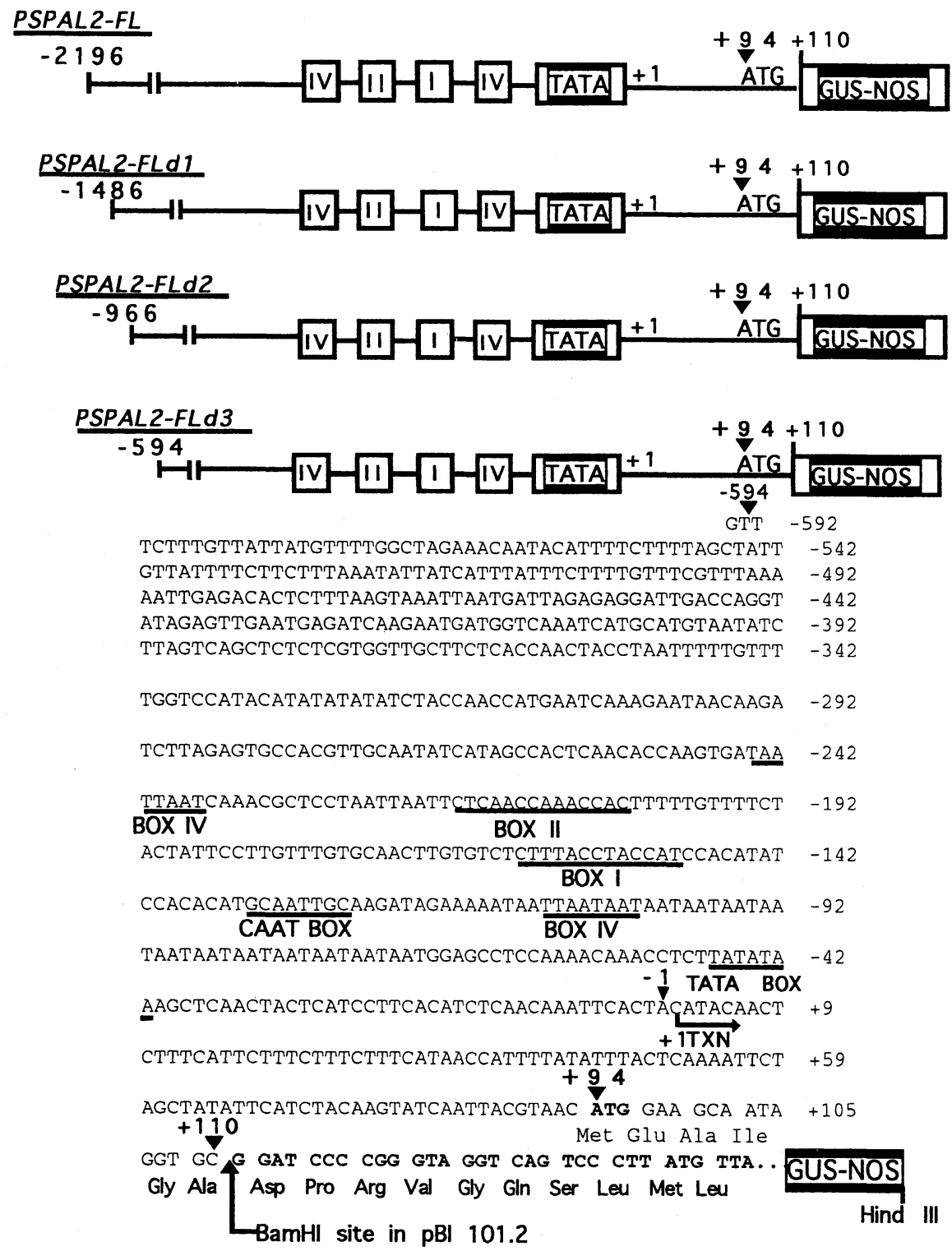

Fig. 1. Schematic representation of PSPAL2 promoter-GUS-NOS fusions. Full-length (PSPAL2-FL) promoter-sequence and the three deleted chimeric promoter constructs (PSPAL2-FLd1, PSPAL2-FLd2, and PSPAL2-FLd3) were fused to GUS in pBI101.2 (Toyobo Inc., Kyoto, Japan) at HindIII and BamHI sites. The type of fusions and the positions where GUS-NOS cassette was connected are schematically represented relative to a putative translation initiation codon (ATG) and transcriptional start site (TXN). The nucleotide sequences of all chimeric promoter constructs and the positions where GUS-NOS cassette were connected are shown and indicated with closed triangles. The numbers on top denote the nucleotide position from the transcriptional start point ${ }^{49)}$. Abbreviations : TXN and ATG, putative PSPAL2 transcriptional and translational initiation sites, respectively; GUS and NOS, $\beta$-glucuronidase gene in pBI 101.2 and $A$. tumefaciens nopaline synthase gene terminator sequence, respectively. 
hr of incubation (Plate I), where a plant defense system had presumably been established for blocking fungal invasion, in a manner similar to the expression of PSPAL1 promoter ${ }^{23)}$. The pattern of GUS expression after inoculation with a pathogen was not as clear as the one observed in the necrotic area after inoculation with a nonpathogen and never faded until the whole leaf was colonized.

\section{Expression of deleted PSPAL2 promoter after fungal infection}

To discriminate the expression of the deleted PSPAL2 promoter upon fungal infection, mature leaves of transgenic tobacco plants carrying the PSPAL2 chimeric promoter constructs were inoculated with $P$. capsici. This nonpathogenic fungus induced a very large, clear GUS expression zone around the site of the hypersensitive response (HR), especially in the transformants of PSPAL2-FL (Plate II : A) and PSPAL2-FLd1 (Plate II : B) at $48 \mathrm{hr}$ after the inoculation. However, the responses to fungal infection were not as high in the transformants of PSPAL2-FLd2 (Plate II : C); the expression zone was restricted to the area around the inoculation site. GUS expression in the transformant of PSPAL2-FLd3 was almost negligible (Plate II : D). The results showed that the pea PSPAL2 promoter expression in transgenic tobacco is strongly affected by the sequences in the $5^{\prime}$-upstream region as previously shown with transient CAT expression in electroporated pea protoplasts $^{48)}$. The functional analysis of $5^{\prime}$ nested deletions of PSPAL2 promoter in electroporated pea protoplasts showed that an enhancer-like element is located at the TATA-distal region from -2196 to -406 , and this promoter was activated by the fungal elicitor from $M$. pinodes and partially suppressed by the suppressor from the same fungus ${ }^{48}$.

Interestingly, the GUS expression of our constructs upon fungal ingression in transgenic tobacco leaves demonstrated the induction of positive defense responses at the sites of infection at different levels depending on the additional sequences at the $5^{\prime}$-upstream region. Because we have observed a very low level of GUS expression in all the transformants of PSPAL2FLd3 compared to PSPAL2-FL, the lower level of GUS expression is not likely due to a position effect of the integration of the chimeric gene. This phenomenon may be explained by the lack of some active elements that are needed for the regulation of the PSPAL2 promoter. These elements are likely to span from -966 to -2196 . Moreover, we have observed GUS expression in mature transgenic tobacco leaves injured with sterile razor blade histochemically. Intense blue colorations were observed at wounded sites (W) and restricted adjacent areas. The GUS expression of the deleted PSPAL2 promoter after wounding also declined from a high level to an extremely low one as the deletion was extended, in a manner similar to the expression after fungal ingression (Plate II : E-H).

\section{DISCUSSION}

In a previous study, we found that the pea phenylalanine ammonia-lyase gene2 (PSPAL2) promoter was induced by a fungal elicitor and suppressed by suppressors isolated from a pea pathogen, $M$. pinodes ${ }^{49}$. The expression of plant genes can be induced by environmental stresses such as wounding, UV irradiation, abiotic and biotic elicitors. For example, regulation of promoters of the Arabidopsis STP4 gene (for sugar transport protein ${ }^{4}$ under the stresses of wounding, elicitors, and pathogen challenge ${ }^{45}$ and of the melon ACC (1aminocyclopropane-1-carboxylate) oxidase gene in transgenic tobacco plants under the stresses of wounding, pathogen attack and treatment with ethylene or copper sulfate $^{3)}$ were also reported. Recently, the pea phenylalanine ammonia-lyase gene1 (PSPAL1) promoter was found to exhibit a temporal and spatial pattern of GUS expression in response to pathogen ingress and wounding in transgenic tobacco ${ }^{23)}$. In this paper, we have for the first time demonstrated the expression of pea PSPAL2 full-length promoter (PSPAL2-FL) and the three types of sequentially deleted chimeric promoter constructs designated as PSPAL2-FLd1, PSPAL2-FLd2 and PSPAL2-FLd3 in transgenic tobacco upon fungal ingression. We observed basal GUS expression in tissues of roots, stems and leaves during developmental in vitro growth of young seedlings before transplanting to soil. The levels of GUS activity in tissues of transgenic plants which had been transformed with an additional sequence at the $5^{\prime}$-upstream PSPAL2 promoter were also determined. Extremely low GUS expression was observed in healthy or undisturbed mature leaves (data not shown). However, the PSPAL2 promoter in leaves of transgenic tobacco plants after transfer to the greenhouse was induced upon fungal ingression, especially when leaves inoculated with $P$. capsici were incubated at $22-24^{\circ} \mathrm{C}$ for $48 \mathrm{hr}$. Marked expression was detected at the HR area surrounding the inoculation site of the transformant of PSPAL2-FL (Plate II : A). Extremely low GUS expression was observed in the transformant of PSPAL2-FLd3 (Plate II : D) although brown necrotic regions developed at the cross cut (Plate II : D). The results demonstrated that the region from -966 to -2196 of PSPAL2 promoter play a crucial role in the regulation of induction of GUS activities in the mature leaves of transgenic tobacco plants. Moreover, we have observed the induction of GUS expression in wounded mature leaves. The GUS expression in response to cut injury also declined in leaves transformed with the deleted promoter constructs in a manner similar to the expression after fungal ingress (Plate II : $\mathrm{E}-\mathrm{H}$ ). It is thus clear that the $5^{\prime}$-upstream region between +110 to -594 , which contains important box sequences such as box I, box II and box IV as shown in Fig. $1^{48)}$, was insufficient to establish the full capacity of defense gene response under stresses. The additional sequences from -594 to -2196 are 
obviously necessary for the functional expression of the gene. The role of the $5^{\prime}$-upstream region in plant defense responses has been widely studied in terms of regulation in transgenic tobacco. The study of the significance of the $5^{\prime}$-upstream region of the pathogenesis-related protein (PR) 1a promoter which contains the flanking regions up to -906 and -1533 revealed its regulatory function in expression in transgenic tobacco under stresses of pathogen attack and abiotic elicitor. All tobacco transformants exhibited induced GUS expression after infection with tobacco mosaic virus or treatment with acetylsalicylic acid $^{16)}$. Recently, the link between the activation of retrotransposons and plant defense responses has been suggested in relation to possible genome restructuring that is needed in response to environmental fluctuations such as pathogen attacks and wounding ${ }^{14,15,33)}$. In our study, we have found retrotransposon-like sequences in the $5^{\prime}$-upstream regions of $P S P A L 2$ and of another elicitor-inducible defense gene, PSCHS1 (chalcone synthase gene1 in Pisum sativum: -2772 to -530$)^{20}$. Interestingly, these putative sequence motifs are located in the region between -966 and -2196 in which we found higher GUS expression as a defense response to fungal ingression in transgenic tobacco plants. The role of active elements or other related factors that are involved in plant defense-related PSPAL2 promoter expression under environmental stresses, especially the functional relationship to retrotransposon-like sequence, will be reported elsewhere.

The authors are grateful to Prof. Dr. Thira Sutabutra for valuable advice and Ms. Anchalee Raweerojwiboon for technical assistance during the experiment in Kasetsart University, Thailand. This research was supported in part by a grant from the Japan Society for the Promotion of-Science (JSPS) under the JSPS RONPAKU (Dissertation Ph.D) Program ID No. NRCT-9629, and also in part by a grant from Okayama University for the specific research "The study of the development of organisms effective to environmental conservation for human life" at Okayama University in 1998 1999.

\section{Literature cited}

1. Bailey, J.A. (1982). Mechanisms of phytoalexin accumulation. In Phytoalexin (Bailey, J.A. and Mansfield, J.W. eds.), Halste/Wiley, New York, pp. 289-318.

2. Bevan, M., Shufflebottom, D., Jefferson, R. and Schuch, W. (1989). Cell- and tissue-specific activity of phenylalanine ammonia-lyase promoter in transgenic plants. EMBO J. 8 : 1899-1906.

3. Bouquin, T., Lasserre, E., Pradier, J., Pech, J.C. and Balague, C. (1997). Wound and ethylene induction of the ACC oxidase melon gene CM-AC01 occurs via two direct and independent transduction pathways. Plant Mol. Biol. 35 : 1029-1035.

4. Bowles, D. (1990). Signals in the wounded plant. Nature $343:$ :314-315.
5. Choudhary, A.D., Kessmann, H., Lamb, C.J. and Dixon, R.A. (1990). Stress responses in alfalfa (Medicago sativa L.). IV. Expression of defense gene constructs in electroporated cell protoplasts. Plant Cell Rep. 9 : 42-46.

6. Dangle, J.L., Hauffe, K.D., Lipphardt, S., Hahlbrock, K. and Scheel, D. (1987). Parsley protoplasts retain differential responsiveness to u.v. light and fungal elicitor. EMBO J. 6 : 25551-2556.

7. Dixon, R.A. and Paiva, N.L. (1995). Stress-induced phenylpropanoid metabolism. Plant Cell 7 : 1085-1097.

8. Dron, M., Clouse, S.D., Dixon, R.A., Lawton, M.A. and Lamb, C.J. (1988). Glutathione and fungal elicitor regulation of a plant defense gene promoter in electroporated protoplasts. Proc. Natl. Acad. Sci. USA 85 : 67386742.

9. Esau, K. (1977). Anatomy of Seed Plants, John Wiley \& Son, Inc., New York.

10. Fukazawa-Akada, T., Kung, S. and Watson, J.C. (1996). Phenylalanine ammonia-lyase gene structure, expression, and evolution in Nicotiana. Plant Mol. Biol. 30 : 711-722.

11. Gelvin, S.B., Schilperoort, R.A. and Verma, D.P.S. (1990). Plant Molecular Biology Manual, Kluwer Academic Publishers, New York.

12. Goodman, R.N. and Novacky, A.J. (1994). The Hypersensitive Reaction in Plants to Pathogens : A Resistance Phenomenon, APS Press, St. Paul, Minnesota.

13. Gowri, G., Paiva, N.L. and Dixon, R.A. (1991). Stress responses in alfalfa (Medicago sativa). 12. Sequence analysis of phenylalanine ammonia-lyase (PAL) cDNA clones and appearance of PAL transcripts in elicitortreated cell cultures and developing plants. Plant Mol. Biol. 17 : 415-426.

14. Grandbastien, M.A., Audeon, C., Casacuberta, J.M., Grappin, P., Lucas, H., Moreau, C. and Pouteau, S. (1994). Functional analysis of the tobacco Tnt1 retrotransposon. Genetica 93 : 181-189.

15. Grandbastien, M.A., Lucas, H., Morel, J.B., Mhiri, C., Vernhettes, S. and Casacuberta, J.M. (1997). The expression of the tobacco Tnt1 retrotransposon is linked to plant defense responses. Genetica $100: 241-$ 252.

16. Gruner, R. and Pfitzner, U.M. (1994). The upstream region of the gene for the pathogenesis-related protein 1a from tobacco responds to environmental as well to developmental signals in transgenic plants. Eur. J. Biochem. $220:$ 247-255.

17. Harrison, M.J., Choudhary, A.D., Dubery, I., Christopher, J.L. and Dixon, R.A. (1991). Stress response in alfalfa (Medicago sativa L.). Cis-elements and transfactors for the quantitative expression of a bean chalcone synthase gene promoter in electroporated alfalfa protoplasts. Plant Mol. Biol. 16: 877-890.

18. Holsters, M., de Waele, D., Depicker, A., Messens, E., van Montagu, M. and Schell, J. (1978). Transfection and transformation of Agrobacterium tumefaciens. Mol. Gen. Genet. 163 : 181-187.

19. Hosaka, K. (1994). Current RAPD Technology, Academic Booklet, Kobe University, Kobe.

20. Ito, M., Ichinose, Y., Kato, H., Shiraishi, T. and Yamada, T. (1997). Molecular evolution and functional 
relevance of the chalcone synthase genes of pea. Mol. Gen. Genet. 255 : 28-37.

21. Jakobek, J.L., Smith, J.A. and Lindgren, P.B. (1993). Suppression of bean defense responses by Pseudomonas syringae. Plant Cell 5 : 57-63.

22. Jefferson, R.A., Kavanagh, T.A. and Bevan, M.W. (1987). GUS fusion: $\beta$-glucuronidase as a sensitive and versatile gene marker in higher plants. EMBO J. 6 : 3901-3907.

23. Kawamata, S., Shimoharai, K., Imura, Y., Ozaki, M., Ichinose, Y., Shiraishi, T., Kunoh, H. and Yamada, T. (1997). Temporal and spatial pattern of expression of the pea phenylalanine ammonia-lyase gene1 promoter in transgenic tobacco. Plant Cell Physiol. 38: 792-803.

24. Kiba, A., Toyoda, K., Ichinose, Y., Yamada, T. and Shiraishi, T. (1996). Specific response of partially purified cell wall-bound ATPases to fungal suppressor. Plant Cell Physiol. 37 : 207-214.

25. Lamb, C.J., Lawton, M.A., Dron, M. and Dixon, R.A. (1989). Signals and transduction mechanisms for activation of plant defense against microbial attack. Cell 56:215-224.

26. Lasserre, E., Godard, F., Bouquin, T., Hernandez, J.A., Pech, J.C., Roby, D. and Balague, C. (1997). Differential activation of two ACC oxidase gene promoters from melon during plant development and in response to pathogen attack. Mol. Gen. Genet. 256 : 211-222.

27. Lee, S.W., Robb, J. and Nazar, R.N. (1992). Truncated phenylalanine ammonia-lyase expression in tomato (Lycopersicon esculentum). J. Biol. Chem. 267: 1182411830.

28. Leyva, A., Liang, X., Pintor-Toro, J.A., Dixon, R.A. and Lamb, C.J. (1992). Cis-element combinations determine phenylalanine ammonia-lyase gene tissue-specific expression patterns. Plant Cell 4 : 263-271.

29. Lois, R., Dietrich, A., Hahlbrock, K. and Schulz, W. (1989). A phenylalanine ammonia-lyase gene from parsley: structure, regulation and identification of elicitor and light responsive cis-acting elements. EMBO J. $8: 1641-1648$.

30. Mauch-Mani, B. and Slusarenko, A. (1996). Production of salicylic acid precursors in a major function of phenylalanine ammonia-lyase in the resistance of $\mathrm{Arabi}$ dopsis to Peronospora parasitica. Plant Cell 8 : 203-212.

31. McCormick, S., Niedermeyer, J. and Fry, J. (1986). Leaf disc transformation of cultivated tomato ( $L$. esculentum) using Agrobacterium tumefaciens. Plant Cell Rep. 5 : 81-84.

32. Memelink, J., Linthorst, H.J.M., Schilperoort, R.A. and Hoge, J.H.C. (1990). Tobacco genes encoding acidic and basic isoforms of pathogenesis-related proteins display different expression patterns. Plant Mol. Biol. $14: 119-126$.

33. Mhiri, C., Morel, J.B., Vernhettes, S., Casacuberta, J.M., Lucas, H. and Grandbastien, M.A. (1997). The promoter of the tobacco Tnt1 retrotransposon is induced by wounding and by abiotic stress. Plant Mol. Biol. 33 : 257-266.

34. Minami, E., Ozeki, Y., Matsuoka, M., Koizuka, N. and Tanaka, Y. (1989). Structure and some characterization of the gene for phenylalanine ammonia-lyase from rice plants. Eur. J. Biochem. $185:$ 19-25.
35. Murashige, T. and Skoog, F. (1962). A revised medium for rapid growth and bioassays with tobacco tissue cultures. Physiol. Plant. 15 : 473-497.

36. Ohl, S., Hedrick, S.A., Chory, J. and Lamb, C.J. (1990). Functional properties of a phenylalanine ammonia-lyase promoter from Arabidopsis. Plant Cell 2: 837-848.

37. Sablowski, R.W.M., Baulcombe, D.C. and Bevan, M. (1995). Expression of a flower-specific Myb protein in leaf cells using a viral vector causes ectopic activation of a target promoter. Proc. Natl. Acad. Sci. USA 92 : 6901-6905.

38. Sambrook, T., Fritsch, E.F. and Manitis, J. (1989). Molecular Cloning: A Laboratory Manual, Cold Spring Harbor, New York.

39. Shafflebottom, D., Edwards, K., Schuch, W. and Bevan, M. (1993). Transcription of two members of a gene family encoding phenylalanine ammonia-lyase leads to remarkably different cell specificities and induction patterns. Plant J. 3 : 635-645.

40. Shiraishi, T., Saitoh, K., Kim, H.-M., Kato, T., Tahara, M., Oku, H., Yamada, T. and Ichinose, Y. (1992). Two suppressors, Supprescins A and B, secreted by a pea pathogen Mycosphaerella pinodes. Plant Cell Physiol. 33 : 663-667.

41. Strabala, T.J., Crowell, D.N. and Amasino, R.M. (1993). Levels and location of expression of the Agrobacterium tumefaciens pTiA6 ipt gene promoter in transgenic tobacco. Plant Mol. Biol. 21 : 1011-1021.

42. Subramaniam, R., Reinold, S., Molitor, E.K. and Douglas, C.J. (1993). Structure, inheritance, and expression of hybrid poplar (Populus trichocarpa $\times$ Populus deltoides) phenylalanine ammonia-lyase genes. Plant Physiol. 102 : 71-83.

43. Takeda, J., Ozeki, Y. and Yoshida, K. (1997). Action spectrum for induction of promoter activity of phenylalanine ammonia-lyase gene by UV in carrot suspension cells. Phytochem. Photobiol. 66 : 464-470.

44. Tanaka, Y., Matsuoka, M., Yamamoto, N., Ohashi, Y., Kano-Murakami, Y. and Ozeki, Y. (1989). Structure and characterization of a cDNA for phenylalanine ammonia-lyase from cut-injured roots of sweet potato. Plant Physiol. 90 : 1403-1407.

45. Truernit, E., Schmid, J., Epple, P., Illig, J. and Sauer, N. (1996). The sink-specific and stress-regulated Arabidopsis STP4 gene : enhanced expression of a gene encoding a monosaccharide transporter by wounding, elicitors, and pathogen challenge. Plant Cell 8 : 2169-2182.

46. Wanner, L.A., Li, G., Ware, D., Somssich, I.E. and Davis, K.R. (1995). The phenylalanine ammonia-lyase gene family in Arabidopsis thaliana. Plant Mol. Biol. 27 : 327-338.

47. Whetten, R.W. and Sederoff, R.R. (1992). Phenylalanine ammonia-lyase from loblolly pine: purification of the enzyme and isolation of complementary DNA clones. Plant Physiol. 98 : 380-386.

48. Yamada, Y., Sriprasertsak, P., Kato, H., Hashimoto, T., Shimizu, H. and Shiraishi, T. (1994). Functional analysis of the promoters of phenylalanine ammonia-lyase genes in pea. Plant Cell Physiol. 35 : 917-926.

49. Yamada, Y., Tanaka, Y., Sriprasertsak, P., Kato, H., Hashimoto, T., Kawamata, S., Ichinose, Y., Kato, H., 
Shiraishi, T. and Oku, H.(1992). Phenylalanine ammonia-lyase genes from Pisum sativum: structure, organ-specific expression and regulation by fungal elicitor and suppressor. Plant Cell Physiol. 33 : 715-725.

50. Yazaki, K., Kataoka, M., Honda, G., Severin, K. and Heide, L. (1997). cDNA cloning and gene expression of phenylalanine ammonia-lyase in Lithospermum erythrorhizon Biosci. Biotech. Biochem. 61: 1995-2003.

51. Zhu, Q., Dabi, T., Beeche, A., Yamamoto, R., Lawton, M.A. and Lamb, C.J. (1995). Cloning and properties of a rice gene encoding phenylalanine ammonia-lyase. Plant Mol. Biol. 29 : 535-550.

\section{和 文 摘 要}

Permpong SRIPRASERTSAK ・ Andi SALAMAH ・井村善之・D 瀬勇規・白石友紀・山田哲治：エンドウ・PAL キメラ遺伝子プ ロモータを導入したトランスジェニック・タバコにおける菌類 感染および傷害に対する発現の解析
5’PAL 遺伝子プロモータ上流領域（-2196〜+110）を順次 削り取り，GUSレポーター遺伝子に連結したキメラ遺伝子を夕 バコに導入後, 4 種 PSPAL2-FL (-2196〜+110), PSPAL2FLd1 (-1486〜+110), PSPAL2-FLd2 (-966〜+110), PSPAL2-FLd3（－594～+110）のトランスジェニック植物体 を作出した。トランスジェニックタバコ葉におけるGUS 発現 様式を組織学的に観察したところ, タバコの非病原菌 (Phytophthora capsici) 接種において, PSPAL2-FL およびPSPAL2$F L d I$ 導入体では, 接種 2 日目で過敏感反応を起こした組織の 周辺細胞できわめて顕著な GUS 発現が検出されたのに対し， 病原菌 (Phytophthora nicotiana) 接種葉では, 微弱な GUS 発現 が接種部位周辺に拡がって検出された。また,剃刀でタバコ葉に 付傷した場合にも顕著な GUS 発現がみられた。これらの結 果は, PSPAL2 の遺伝子発現は病原菌接種に限らず，傷によっ ても誘導されること，本発現にはプロモー夕上流域（-2196〜 -966）が必要であることを示している。

\section{Explanation of plates}

Plate I Histochemical GUS expression of PSPAL2-FL promoter upon wounding (W) and fungal ingression with a pathogen (P, P. nicotianae) and nonpathogen (NP, P. capsici) in transgenic tobacco leaves. Control treatment is shown as C.

A : $24 \mathrm{hr}$ after inoculation or wounding

B : $48 \mathrm{hr}$ after inoculation or wounding

$\mathrm{C}: 72 \mathrm{hr}$ after inoculation or wounding

Plate II Expression of full-length (PSPAL2-FL : A, E) and deleted PSPAL2 promoters (PSPAL2-FLd1 : B, F ; PSPAL2-FLd2 : $\mathrm{C}, \mathrm{G} ;$ PSPAL2-FLd3 : D, H) at $48 \mathrm{hr}$ after wounding $(\mathrm{W})$ and inoculation with a nonpathogen (NP, $P$. capsici) in transgenic tobacco leaves. Bars equal $1 \mathrm{~mm}$.

\section{Plate I}

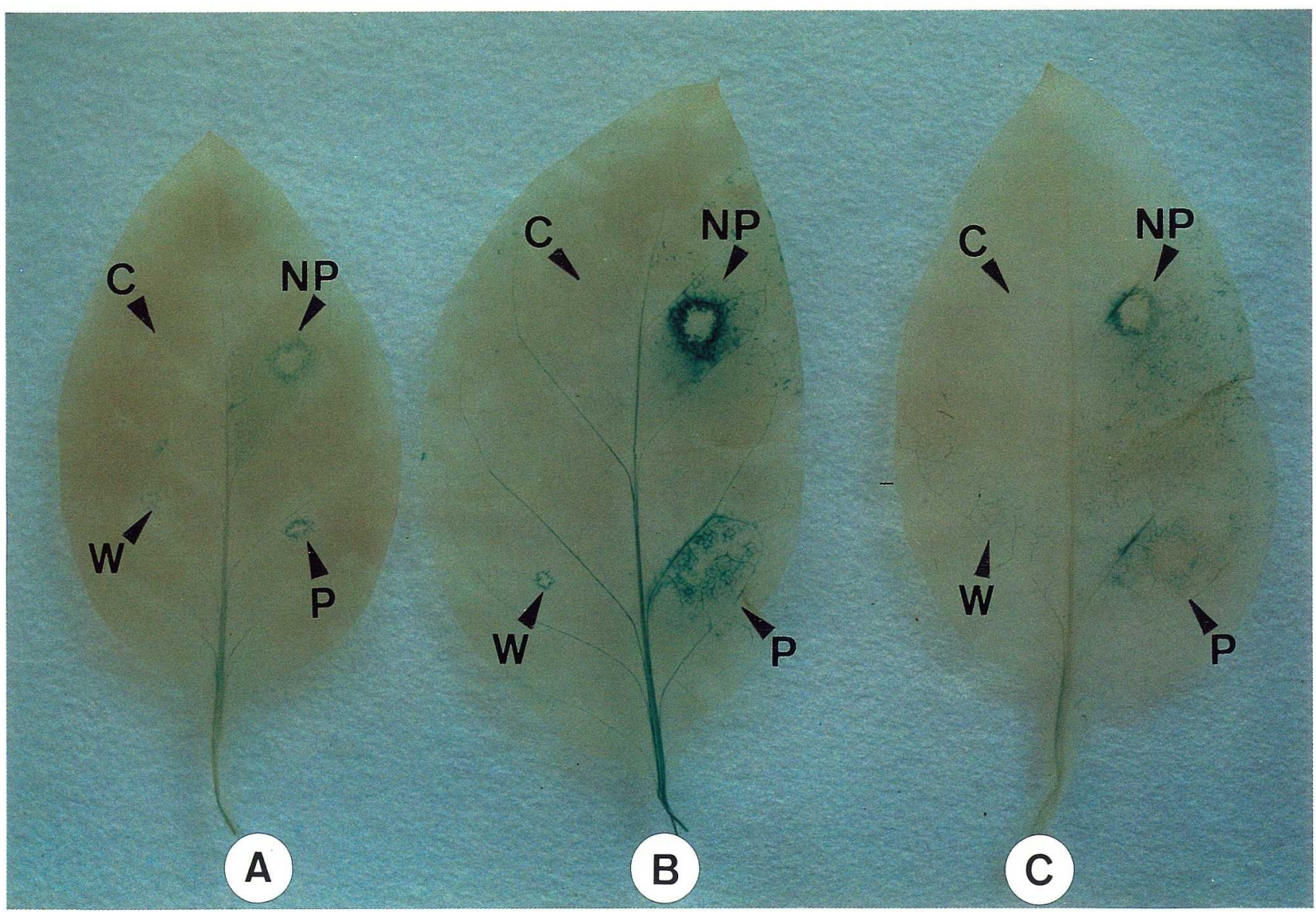


Plate II
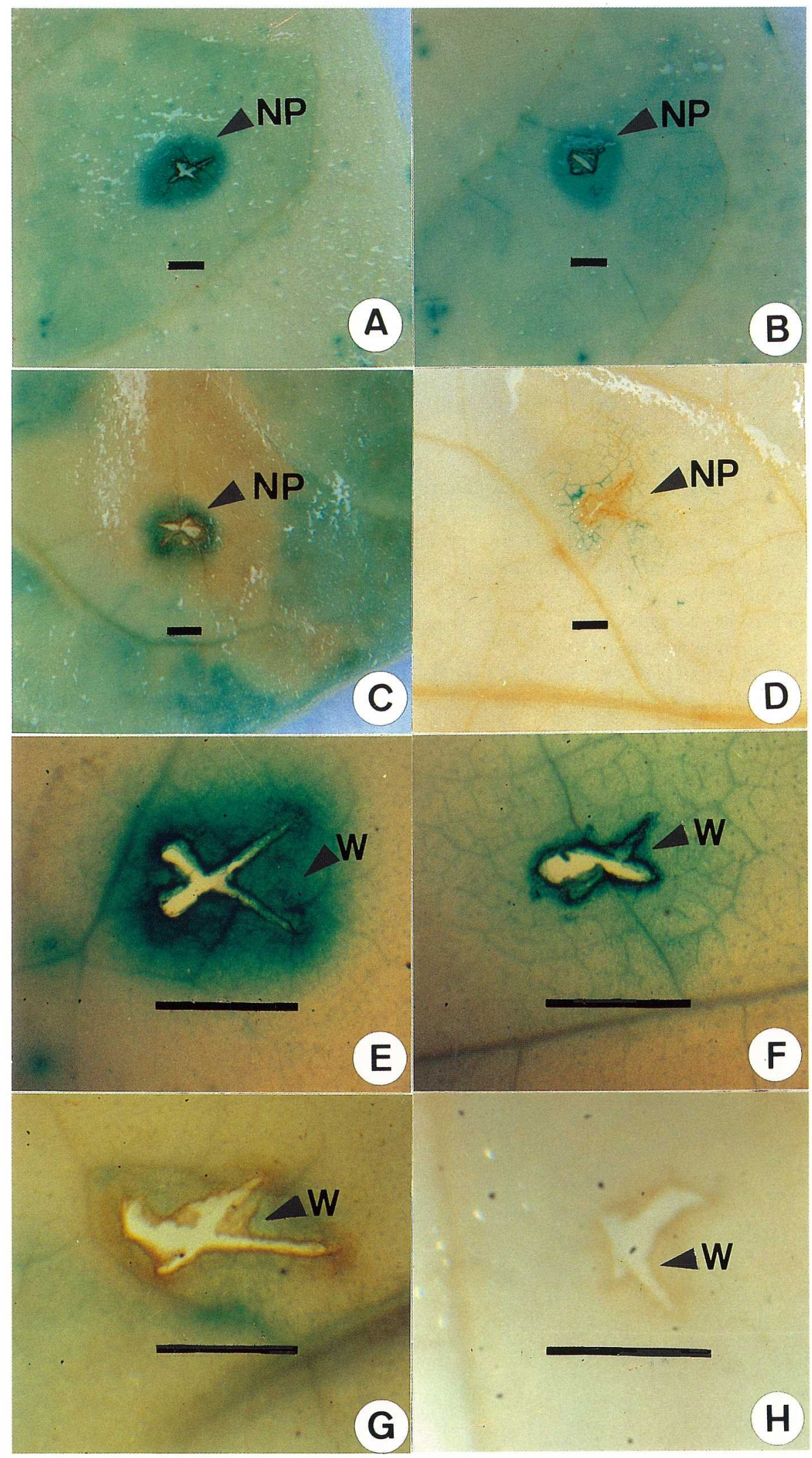